\title{
COMPATIBILITY BETWEEN THE STEM VOLUME AND TAPER EQUATIONS VOLUME FOR BLACK WATTLE TREES
}

\author{
Marcos Behling $^{1 *}$, Henrique Soares Koehler ${ }^{2}$, Alexandre Behling ${ }^{3}$ \\ ${ }^{1 *}$ Federal University of Paraná, Department of Forest Resources, Curitiba, Paraná, Brazil - mcosbehling@ gmail.com \\ ${ }^{2}$ Federal University of Paraná, Graduation Program..., Curitiba, Paraná, Brazil - koehler@ufpr.br \\ ${ }^{3}$ Federal University of Paraná, Graduation Program..., Curitiba, Paraná, Brazil - alexandre.behling@yahoo.com.br
}

Received for publication: 14/12/2018 - Accepted for publication: 27/08/2019

\begin{abstract}
Resumo
Um sistema de equação muito utilizado pela Engenharia Florestal na comunidade internacional de pesquisadores consiste na combinação de uma função volumétrica com uma função de afilamento, visando compatibilizar as estimativas volumétricas. No caso do sistema compreendendo a função de volume e de afilamento, o resultado do volume estimado por essas duas funções deve ser compatível, ou seja, o volume obtido pela função volumétrica não deve diferir do volume obtido por meio de integração valendo-se da função de afilamento. Assim, o objetivo desta pesquisa foi desenvolver e apresentar os procedimentos de um sistema de equações para compatibilizar as estimativas volumétricas da equação de volume e de afilamento e comparar com a abordagem tradicional, que é aplicada nas empresas florestais. Os procedimentos propostos foram aplicados em dados da espécie Acacia mearnsii De Wild. (acácia negra) nos locais que concentram os plantios da espécie no estado do Rio Grande do Sul. O conjunto de dados foi composto por 343 árvores com idade variando de 5 a 10,75 anos. Foi observado que a não compatibilidade do volume, em termos absolutos da unidade de medida, aumenta exponencialmente em função do tamanho da árvore. A qualidade das estimativas por meio do sistema de equações compatíveis não diferiu daquelas obtidas por meio da modelagem tradicional, portanto, é preferível. Ainda, foi identificado que os resíduos das equações de volume e de afilamento são correlacionados, o que sugere que o sistema de equações seja ajustado simultaneamente.

Palavras-chave: Incompatibilidade do volume, regressão aparentemente não relacionada, correlação dos resíduos.
\end{abstract}

\begin{abstract}
A system of equations widely used in Forest Engineering by the international community of researchers consists of a combination of a volumetric function and a taper function, with the purpose of making volume estimates compatible. When using the volume function and the taper function in a system, the result of the volume estimated by the two functions should be compatible, meaning that the volume estimated by the volumetric function should not differ from the volume obtained by integrating the taper function. Thus, the purpose of this paper was to develop and present the procedures of a system of equations to make volume estimates from both volume and taper equations compatible, and then compare it to the traditional approach, which is used in forestry companies. The procedures proposed were applied to a data set on the Acacia mearnsii De Wild. (black wattle) at sites where the plantation of this species is concentrated in the state of Rio Grande do Sul. The data set included 343 trees ranging from 5 to 10.75 years of age. It was noted that the lack of volume compatibility, in absolute terms, grows exponentially with the size of the tree. The quality of the estimates using the system of compatible equations did not differ from those obtained from the traditional model, therefore, the former is preferable. Furthermore, it was noted that the residuals from the volume and taper equations are correlated, which suggests that the system of equations be fitted simultaneously.
\end{abstract}

Keywords: Volume incompatibility, seemingly unrelated regression, residual correlation.

\section{INTRODUCTION}

There are two main methods to estimate the stem volume and develop models to estimate stem volume, namely: $i$ ) develop a model to estimate the stem volume for a fixed upper diameter; $i$ ) develop a taper function and get estimates of the merchantable volume by parts, and in total using the integration of the taper function.

The first approach is known as the volumetric function for the stem total volume. The second is known as the taper function, which is notoriously accurate to estimate diameters along the stem, and by integrating it, calculate volumes at several sections of the stem. Obviously, the total volume can be obtained as well, but not with the same accuracy as in the first approach.

Optimally, the tree's volume equations should be compatible, where the stem total volume estimates should not differ when using a total volume equation and when calculating the volume by integrating the taper equation (CLUTTER, 1980). Several times this condition is overlooked, i.e., the lack of compatibility between

FLORESTA, Curitiba, PR, v. 50, n. 3, p. 1518 - 1526, jul/set 2020.

Behling, M. et.al.

ISSN eletrônico 1982-4688

DOI: $10.5380 /$ rf.v50 i3. 63881 
volume predictions made using the two approaches is clearly demonstrated. It is a practical issue in which both companies and researchers have some interest.

Thus, the reason for this paper is grounded on the development and presentation of an approach that makes the volume equations compatible. A system of compatible equations consists of a total volume equation and a taper equation, where the total volume estimation calculated using these two equations should not be different. In this system the total volume equation is used to easily estimate a tree's total volume, and the taper equation to estimate the volume by parts, according to the desirable assortments.

A simple method that results in compatible and accurate predictions of the total volume and volume by parts, therefore, is rather useful for the practical management of forests and, specially, for volumetric results of forest inventories. These compatible equations are an efficient and flexible way to estimate the tree's total volume and volume by parts, and it can, therefore, meet the demands of the market trends as the products' specifications change.

The overall objective of this study aimed to develop and present procedures for a system of equations to make the volume estimates from the total volume equation and from the taper equation compatible for trees of the Acacia mearnsii De Wild species. More specifically, the objective was to apply the procedures of the system of equations to model the stem volume using total volumetric function and taper function aiming to ensure their compatibility, quantify and assess the incompatibility of the volume estimates obtained from volumetric function equations and taper functions fitted in an independent manner, and compare the volume estimates from independently fitted equations and from the system of equations.

\section{MATERIALS AND METHODS}

\section{Source of the data}

The data was sampled from stands of black wattle in the state of Rio Grande do Sul, in the surroundings of the municipalities of Cristal, Encruzilhada do Sul, and Piratini (Table 1). These regions concentrate most plantations of this species.

Four circular plots with a diameter of 10 meters $\left(78.54 \mathrm{~m}^{2}\right)$ were randomly allocated at each stand. All trees in the plots were felled and the following characteristics were measured: diameter at breast height, total height and cubic volume of the stem. Thus, this study involved the allocation of 24 temporary sample plots, whose central coordinates are shown in Table 1, and 343 trees from the plots were measured.

Table 1: Central coordinates of the 24 sample plots allocated in black wattle stands in the state of Rio Grande do Sul, Brazil.

Tabela 1: Coordenadas centrais das 24 unidades amostrais instaladas em povoamentos de acácia negra no estado do Rio Grande do Sul, Brasil.

\begin{tabular}{|c|c|c|c|c|c|c|c|c|}
\hline \multicolumn{3}{|c|}{ Cristal } & \multicolumn{3}{|c|}{ Encruzilhada do Sul } & \multicolumn{3}{|c|}{ Piratini } \\
\hline A & $\mathrm{S}$ & $\mathrm{W}$ & A & $\mathrm{S}$ & W & A & $\mathrm{S}$ & $\mathrm{W}$ \\
\hline 5 & $30^{\circ} 50^{\prime} 42.8^{\prime \prime}$ & $52^{\circ} 02^{\prime} 26.4^{\prime \prime}$ & 5.75 & $31^{\circ} 04^{\prime} 50.1^{\prime \prime}$ & $53^{\circ} 03^{\prime} 28.8^{\prime \prime}$ & 5.25 & $31^{\circ} 20^{\prime} 22.4^{\prime \prime}$ & $52^{\circ} 56^{\prime} 33.5^{\prime \prime}$ \\
\hline 5 & $30^{\circ} 50^{\prime} 42.2^{\prime \prime}$ & $52^{\circ} 02^{\prime} 31.1^{\prime \prime}$ & 5.75 & $31^{\circ} 05^{\prime} 13.4^{\prime \prime}$ & $53^{\circ} 04^{\prime} 19.8^{\prime \prime}$ & 5.25 & $31^{\circ} 20^{\prime} 41.5^{\prime \prime}$ & $52^{\circ} 56^{\prime} 40.7^{\prime \prime}$ \\
\hline 5 & $30^{\circ} 50^{\prime} 50.0^{\prime \prime}$ & $52^{\circ} 03^{\prime} 02.9^{\prime \prime}$ & 5.75 & $31^{\circ} 03^{\prime} 56.5^{\prime \prime}$ & $53^{\circ} 03^{\prime} 56.5^{\prime \prime}$ & 5.25 & $31^{\circ} 20^{\prime} 44.0^{\prime \prime}$ & $52^{\circ} 56^{\prime} 34.3^{\prime \prime}$ \\
\hline 5 & $30^{\circ} 50^{\prime} 49.1^{\prime \prime}$ & $52^{\circ} 03^{\prime} 06.8^{\prime \prime}$ & 5.75 & $31^{\circ} 05^{\prime} 23.7^{\prime \prime}$ & $53^{\circ} 04^{\prime} 05.7^{\prime \prime}$ & 5.25 & $31^{\circ} 21^{\prime} 05.4^{\prime \prime}$ & $52^{\circ} 56^{\prime} 45.3^{\prime \prime}$ \\
\hline 10.08 & $31^{\circ} 08^{\prime} 05.4^{\prime \prime}$ & $52^{\circ} 04^{\prime} 35.7^{\prime \prime}$ & 10.75 & $30^{\circ} 27^{\prime} 19.9^{\prime \prime}$ & $52^{\circ} 35^{\prime} 22.3^{\prime \prime}$ & 9.83 & $31^{\circ} 24^{\prime} 34.7^{\prime \prime}$ & $52^{\circ} 58^{\prime} 49.1^{\prime \prime}$ \\
\hline 10.08 & $31^{\circ} 07^{\prime} 51.3^{\prime \prime}$ & $52^{\circ} 04^{\prime} 47.6^{\prime \prime}$ & 10.75 & $30^{\circ} 27^{\prime} 34.5^{\prime \prime}$ & $52^{\circ} 35^{\prime} 47.3^{\prime \prime}$ & 9.83 & $31^{\circ} 24 ' 25.0^{\prime \prime}$ & $52^{\circ} 57^{\prime} 39.2^{\prime \prime}$ \\
\hline 10.08 & $31^{\circ} 07^{\prime} 36.4^{\prime \prime}$ & $52^{\circ} 05^{\prime} 04.1^{\prime \prime}$ & 10.75 & $30^{\circ} 27^{\prime} 32.2^{\prime \prime}$ & $52^{\circ} 36 \prime 23.3^{\prime \prime}$ & 9.83 & $31^{\circ} 24^{\prime} 33.6^{\prime \prime}$ & $52^{\circ} 57^{\prime} 23.0^{\prime \prime}$ \\
\hline 10.08 & $31^{\circ} 07^{\prime} 26.1^{\prime \prime}$ & $52^{\circ} 05^{\prime} 10.8^{\prime \prime}$ & 10.75 & $30^{\circ} 27^{\prime} 35.8^{\prime \prime}$ & $52^{\circ} 36 ' 23.7^{\prime \prime}$ & 9.83 & $31^{\circ} 24^{\prime} 46.5^{\prime \prime}$ & $52^{\circ} 57^{\prime} 26.7^{\prime \prime}$ \\
\hline
\end{tabular}

Key: $\mathrm{I}$ is the age of the stand, in years, $\mathrm{S}$ is the south coordinate, and $\mathrm{W}$ is the west coordinate.

The circumference at breast height $(\mathrm{CBH})$ was measured using a dendrometric measuring tape (in $\mathrm{cm}$ ) and the total height $(h)$ a tape measure (taken in meters). The CBH values were converted into diameters $(d)$. The cubic volume of the stem was measured using a dendrometric measuring tape along the stem at the relative height positions $\left(h_{i}\right)$ of $5 \%, 15 \%, 25 \%, 35 \%, 45 \%, 55 \%, 65 \%, 75 \%, 85 \%$, and $95 \%$ in relation to the total height (where diameters $d_{i}$ were taken in $\mathrm{cm}$ ).

The total stem volume outside bark $\left(v_{f}\right)$ was calculated using Huber's formula. To calculate the total volume a minimum crown diameter outside bark was not taken into account.

FLORESTA, Curitiba, PR, v. 50, n. 3, p. 1518 - 1526, jul/set 2020

Behling, M. et.al.

ISSN eletrônico 1982-4688

DOI: $10.5380 /$ rf.v50 i3. 63881 


$$
v_{f}=\sum_{i=1}^{n} \frac{\pi}{4} d_{i}^{2} l_{i}
$$

Where:

$v_{f}=$ stem total volume outside bark, in $m^{3}$.

$d_{i}=$ diameter measured at the center of the $i$ section segment, in $\mathrm{cm}$.

$l=i$ section length, in $\mathrm{m}$.

\section{Total volume and taper equations}

The total volume and taper equations were estimated using two different approaches: i) independent equations and ii) system of equations.

Spurr's models were tested to estimate the volume and Kozak's models to estimate the diameters along the stem.

$$
\begin{aligned}
& \text { Spurr: } v_{i}=\beta_{0}+\beta_{1}\left(d^{2} h\right)+\varepsilon_{i} \\
& \text { Kozak: } \frac{d_{i}}{d}=\sqrt{\beta_{0}+\beta_{1}\left(\frac{h_{i}}{h}\right)+\beta_{2}\left(\frac{h_{i}}{h}\right)^{2}}+\varepsilon i
\end{aligned}
$$

As the objective of this paper was to quantify the incompatibility of the volume, and the result of the fitting for the two models was satisfactory, other models were not tested. The fitting was assessed by analyzing the following statistics: adjusted coefficient of determination $\left(\bar{R}^{2}\right)$ and standard error of estimate $\left(S_{\bar{y} x}\right)$.

\section{Volume from taper equations and stem volume obtained using independent equations - Procedure 1}

Spurr's and Kozak's volume equations were fitted in an independent manner by applying ordinary least squares estimators. This is the approach traditionally deployed by forestry companies. that:

The stem volume estimated using the taper equation was obtained using Kozak's function integral, such

$$
v=\int_{0}^{h} \frac{\pi}{4} d^{2}\left[b_{0}+b_{1}+\frac{h_{i}}{h}+b_{2}\left(\frac{h_{i}}{h}\right)^{2}\right]
$$

\section{Volume from taper equations and stem volume obtained using systems of equations - Procedure 2}

Demaerschalk (1971, 1972, 1973), Munro and Demaerschalk (1974), and Goulding and Murray (1975) introduced approaches to make the estimated volumes compatible by using the total volume equation with those estimated by using the integration of the taper function. This was known as compatible volume and taper equations, and have been applied by several researchers over the past years, such as: Rodríguez et al. (2013), Tang et al. (2016), Krisnawati (2016), Zheng et al. (2017). Based on those papers we introduce below an approach to make the volumetric equations compatible for a combination of Spurr's volume model and Kozak's taper model, which were applied in this paper.

The most common form used to ensure the compatibility is to express the $\beta$ coefficient of Spurr's combined variable model without the independent term, based on the parameters estimated in a taper function, or vice-versa, using, for this purpose, a proportion of compatibility between two equations. The compatibility is obtained using the volume estimation system derived from Kozak's taper function, according to the following models:

$$
\begin{aligned}
& \text { Spurr: } v=\beta d^{2} h \\
& \text { Kozak: } d_{i}^{2}=\left[\beta_{1}\left(\frac{h_{i}^{2}}{h^{2}}-1\right)-\beta_{2}\left(\frac{h_{i}}{h}-1\right)\right] d^{2}
\end{aligned}
$$

Where:

$v=$ total volume, in $\mathrm{m}^{3}$.

$d=$ diameter at breast height, in $\mathrm{cm}$.

$h=$ total height, in $\mathrm{m}$.

$d_{i}=$ stem diameter at $h_{i}$ height, in $\mathrm{cm}$.

$h_{i}=$ stem height at a given section, in $\mathrm{m}$.

$\beta=$ model parameters to be estimated. 
The integration of the taper function between the base and the apex of the stem turns out to be an expression similar to Spurr's combined variable model, that is:

$$
\begin{aligned}
& v=\int_{0}^{h} \frac{\pi}{4} d_{i}^{2} d h_{i} \\
& v=\int_{0}^{h} \frac{\pi}{4}\left[\beta_{1}\left(\frac{h_{i}^{2}}{h^{2}}-1\right)-\beta_{2}\left(\frac{h_{i}}{h}-1\right)\right] d_{i}^{2} d h_{i} \\
& v=\frac{\pi}{4} d^{2} h\left(\frac{\beta_{2}}{2}-\frac{2 \beta_{1}}{3}\right) \\
& v=\beta d^{2} h, \text { where } \beta=\frac{\pi}{4}\left(\frac{\beta_{2}}{2}-\frac{2 \beta_{1}}{3}\right)
\end{aligned}
$$

Thus, the compatibility between the total volume function and the taper function is due to the $\beta$ parameter of the total volume function, and it is given by the relation with the $\beta_{i}$ parameters of the taper function, therefore:

$$
\beta=\frac{\pi}{4}\left(\frac{\beta_{2}}{2}-\frac{2 \beta_{1}}{3}\right)
$$

The compatibility between the taper function and the total volume function does not depend on the method used to estimate the parameters. However, in this paper, we chose to fit both equations (total volume function and taper function) using a system of equations where the $\beta$ parameter of the total volume function has to be replaced with the function with the $\beta$ coefficients.

The fitting by means of a system of equations enables to obtain a minimum error sum of squares of the system comprised of the two functions (total volume and taper) as a whole, i.e., simultaneously minimize diameter errors at different heights (taper function) and volume estimate errors (total volume function).

The major problem in relation to the third approach to make the volume of the two functions compatible, regarding the simultaneous fitting, is that the number of observations used in each function is not the same. For each tree there is only one total volume observation to fit the total volume function; however, there is more than one observation per tree to express the diameters at different heights.

To solve this problem a special structure was used to accommodate the data in a table, so the observation of total volume of each tree was repeated at every diameter observation at different heights for the same tree. As in this paper a collection with a fixed number of diameters along the stem was carried out, it was not necessary to use weights (reverse of the number of observations for each tree) to balance the differences in the number of diameter observations along the height of each tree, as usually happens in other studies.

In the system of equations parameters were estimated using seemingly unrelated regressions. This way, the system of compatible volume equations was defined as follows:

Where:

$$
\begin{aligned}
& v=d^{2} h\left[\frac{\pi}{4}\left(\frac{\beta_{2}}{2}-\frac{2 \beta_{1}}{3}\right)\right] \\
& d_{i}=\sqrt{\beta_{1}\left(\frac{h_{i}^{2}}{h^{2}}-1\right)-\beta_{2}\left(\frac{h_{i}}{h}-1\right)} d
\end{aligned}
$$

$v=$ stem volume, in $\mathrm{m}^{3}$.

$d=$ diameter at breast height, in $\mathrm{cm}$.

$d_{i}=$ stem diameter at a $h_{i}$ height, in $\mathrm{cm}$.

$h=$ stem total height, in $\mathrm{m}$.

$\beta_{1}$ and $\beta_{2}=$ model coefficients to be estimated.

The system of equations was estimated simultaneously using seemingly unrelated regressions - SUR), according to Diéguez-Aranda et al. (2006). expressions:

Thus, the system of equations consisting of $v$ and $d_{i}$ models can be presented as the following

$$
\begin{aligned}
& {\left[\begin{array}{l}
y_{1} \\
y_{2}
\end{array}\right]=\left[\begin{array}{cccc}
X_{1} & 0 & \cdots & 0 \\
0 & X_{2} & \cdots & 0
\end{array}\right]\left[\begin{array}{l}
\beta_{1} \\
\beta_{2}
\end{array}\right]+\left[\begin{array}{l}
\varepsilon_{1} \\
\varepsilon_{2}
\end{array}\right]} \\
& y=X \beta+\varepsilon
\end{aligned}
$$

Where:

FLORESTA, Curitiba, PR, v. 50, n. 3, p. 1518 - 1526, jul/set 2020. 
$y_{1}=$ stem volume, in $\mathrm{m}^{3}$.

$y_{2}=$ stem diameter at a $h_{i}$ height, in $\mathrm{cm}$.

$X_{1}=d^{2} h$, in $\mathrm{cm}^{2} \mathrm{~m}$.

$X_{2}=d$, in cm, $\frac{h_{i}^{2}}{h^{2}}-1$ and $\frac{h_{i}}{h}-1$, dimensionless.

$\beta_{1}=$ stem total volume model coefficients.

$\beta_{2}=$ taper model coefficients.

Once the SUR model is defined, the $\beta$ solution is carried out using the generalized least squares - (GLS) estimator. Taking the concepts introduced by Greene (2008), for the SUR model the GLS estimator is given by:

$$
\beta=\left(X^{\prime} \Omega^{-1} X\right)^{-1} X^{\prime} \Omega^{-1} y
$$

The $\Omega$ matrix contains the elements of the residuals matrix of the total volume and taper functions, as it is defined by:

$$
\Omega=\sum \otimes I
$$

Where:

$\sum$ = covariance matrix of the total volume and taper functions' residuals, previously obtained by fitting these two functions in an independent manner using an ordinary least squares estimator $\left[\beta=\left(X^{\prime} X\right)^{-1} X^{\prime} y\right]$.

$\otimes=$ Kronecker's product.

$I=$ an identity matrix of order $n$ (number of observations).

The residuals covariance matrix $\left(\sum\right)$ was obtained from:

Where:

$$
\begin{aligned}
& \sum=\left[\begin{array}{ll}
\sigma_{11} & \sigma_{12} \\
\sigma_{21} & \sigma_{22}
\end{array}\right] \\
& \hat{\sigma}_{i j}=\frac{\varepsilon_{i}^{\prime} \varepsilon_{j}}{\left[\left(n-K_{i}\right)\left(n-K_{j}\right)\right]^{\frac{1}{2}}}
\end{aligned}
$$

$\sigma_{i j}=$ covariance between the disturbances between the total volume and taper functions for each sample observation.

$K_{i}$ and $K_{j}=$ number of parameters of each $i$ and $j$ equation, in this case equivalent to 2 .

$n=$ number of observations.

In this case, the residuals covariance values come from residuals obtained using least squares estimators. That is to say, the total volume and taper equations are estimated independently using the ordinary least squares, thus obtaining the errors associated to each equation, and then, consistently estimate the elements that comprise $\sum$.

As the $\Omega$ matrix is given by its reverse, so the $\beta$ estimator can be defined as:

$$
\beta=\left[X^{\prime}\left(\Sigma^{-1} \otimes I\right) X\right]^{-1} X^{\prime}\left(\Sigma^{-1} \otimes I\right) y
$$

Where: $\Omega^{-1}=\Sigma^{-1} \otimes I$

\section{Assessment of the procedures}

The two procedures were assessed using the following criteria:

i) Quality of the equations' fitting

Estimates of total volume and diameters along the stem were carried out. These estimates were compared using a Chi-squared test to test the hypothesis that the values estimated using both approaches are not different, at $95 \%$ probability.

ii) Compatibility of the volume estimates

The compatibility of the volume estimates was assessed using compatibility. The estimates were deemed compatible if $\widehat{V}_{S}-\widehat{V}_{K}=0$, i.e., if the difference between the volume estimated using Spurr's equation $\left(\widehat{V}_{S}\right)$ and the volume using the integration of the taper equation $\left(\widehat{V}_{K}\right)$ was equal to zero. If this condition were not satisfied, the volume estimates were not deemed compatible.

The incompatibility of the volume estimates (VI) was calculated using the difference between volumes in absolute units: $V I=\widehat{V}_{K}-\widehat{V}_{S}$, and their respective percentage values IRV $\left(I R V=\frac{I V}{\widehat{V}_{K}}\right)$. 


\section{RESULTS}

\section{Volume from taper equations and stem volume obtained using independent equations - Procedure 1}

The equation to estimate the volume resulted in the following coefficients and statistics:

$$
\begin{aligned}
& v_{i}=0.005726+0.368386\left(d^{2} h\right) \\
& \bar{R}^{2}=98.49 \%, S_{\bar{y} x}=7.79 \%
\end{aligned}
$$

The equation to estimate the diameters along the stem resulted in the following coefficients and statistics (which were recalculated for the $d_{i}$ variable):

$$
\begin{aligned}
& d_{i}=d \sqrt{1.114527-1.392878\left(\frac{h_{i}}{h}\right)+0.267001\left(\frac{h_{i}}{h}\right)^{2}} \\
& \bar{R}^{2}=96.90 \%, S_{\bar{y} x}=9.08 \%
\end{aligned}
$$

The fitted equations to estimate stem volume and diameters along the stem are appropriate, once the statistics to assess the quality of the fitting were satisfactory.

\section{Volume from taper equations and stem volume obtained using the system of equations - Procedure 2}

The equation to estimate the volume resulted in the following coefficient and statistics:

$$
\begin{aligned}
& v=d^{2} h\left[\frac{\pi}{4}\left(\frac{1.487297}{2}-\frac{20.386575}{3}\right)\right] \\
& \bar{R}^{2}=98.33 \%, S_{\bar{y} x}=8.20 \%
\end{aligned}
$$

The equation to estimate the diameters along the stem resulted in the following coefficient and statistics:

$$
\begin{aligned}
& d_{i}=d \sqrt{0.3886575\left(\frac{h_{i}^{2}}{h^{2}}-1\right)-1.487297\left(\frac{h_{i}}{h}-1\right)} \\
& \bar{R}^{2}=96.80 \%, S_{\bar{y} x}=9.28 \%
\end{aligned}
$$

The covariance matrix of the equations' residuals (e) of $v$ and $d_{i}$ resulted in:

$$
\begin{array}{c|cc} 
& e_{v} & e_{d_{i}} \\
e_{v} & 0.0003079 & 0.0000126 \\
e_{d_{i}} & 0.0000126 & 0.0000015
\end{array}
$$

The correlation matrix of the equations' residuals $(e)$ of $v$ and $d_{i}$ resulted in:

$$
\begin{array}{c|cc|} 
& e_{v} & e_{d_{i}} \\
e_{v} & 1 & 0.5863 \\
e_{d_{i}} & 0.5863 & 1
\end{array}
$$

Using the correlation matrix, it is noted that the residuals are correlated, therefore, the inclusion of the variance and covariance matrix of the residuals in the fitting of the system of equations contributes to improving the efficiency of the equations, which is discussed by Diéguez-Aranda et al. (2006). That is why it is important to estimate the models of Procedure 2 using SUR.

\section{Quality of the equations' fitting}

The statistics to evaluate the quality of the fitting, $\bar{R}^{2}$ and $S_{\bar{y} x}$, for the volume and taper equations, fitted using procedures 1 and 2, were similar. Furthermore, the same estimates trend was obtained between the values observed and estimated for both procedures (Figure 1). The value of the Chi-squared applied to assess the differences in estimates of value of diameter along the stem using the two procedures was 0.1298 , which is insignificant at an $\alpha=5 \%$ level, indicating that the estimates do not differ between them. These results were also proven for the stem volume estimate, where the Chi-squared value was 0.3979 . 

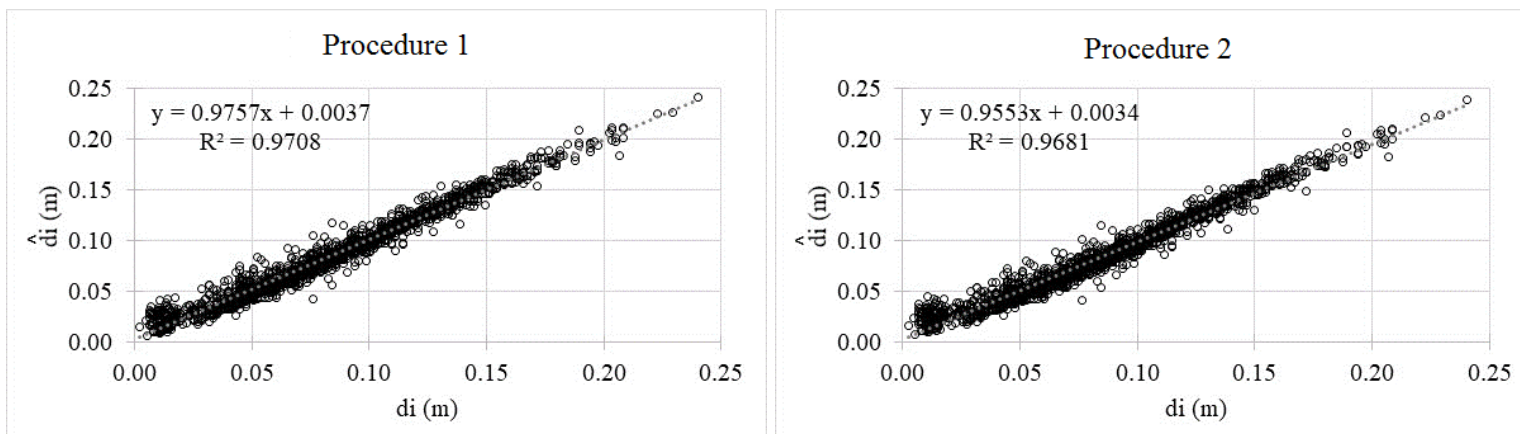

Figure 1. Stem diameter and stem volume values observed and values estimated by using Spurr's and Kozak's fitted model in Procedures 1 and 2, of black wattle trees in the state of Rio Grande do Sul.

Figura 1 - Valores observados de diâmetro ao longo do fuste e volume do fuste e estimados por meio do modelo ajustado de Kozak e de Spurr em função dos Procedimentos 1 e 2, de árvores acácia-negra no estado do Rio Grande do Sul.

Using these statistics, it is noted that the application of both procedures was appropriate to estimate the stem volumes and diameters. However, given the restrictions to obtain compatible equations in Procedure 2, this presents better biological properties. Other compatible volume and taper function systems can be tested and applied, like those proposed by Demaerschalk (1971, 1972, 1973), or other recent ones proposed by Zhao and Kane (2017).

\section{Compatibility of the volume estimates}

The compatible estimates restriction, $\widehat{V}_{S}-\widehat{V}_{K}=0$, was not noted only for the equations obtained using Procedure 1, which were considered non compatible. The volume incompatibility, in absolute terms, increased exponentially with the size of the tree. In relative terms (IRV), this relation was reverse (Figure 2). These differences are small if taken at each tree level (in terms of number of cubic meters of timber), but when the estimators are taken for hectare unit of area, or for the stand total area, they become significant.
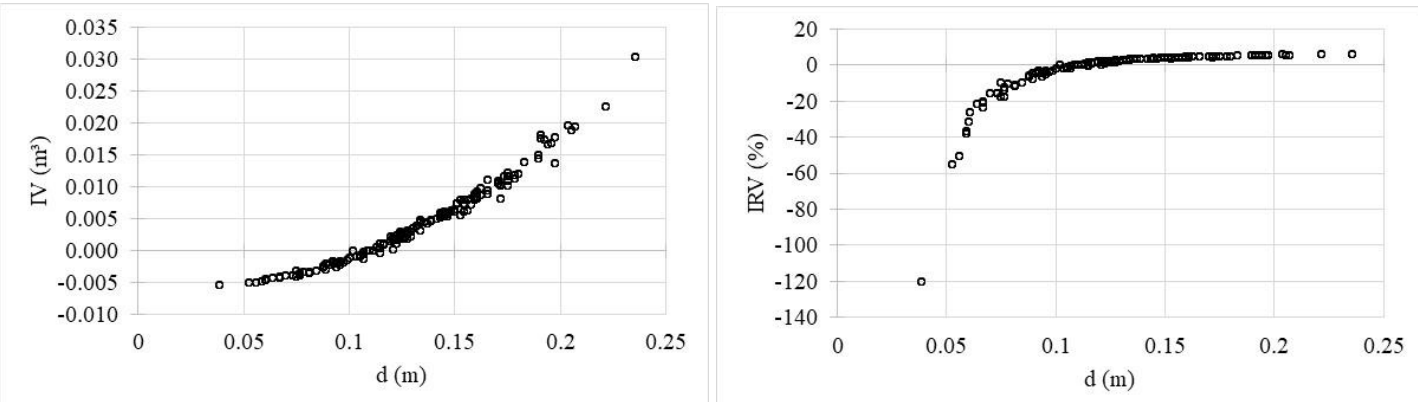

Figure 2. Nonadditivity of the volume estimates obtained using Spurr's equation and integration of Kozak's taper model (Procedure 1) in black wattle trees in Rio Grande do Sul state.

Figura 2 - Não aditividade das estimativas de volume obtidas por meio do modelo ajustado de Spurr e integração do modelo de afilamento de Kozak (Procedimento 1), em árvores de acácia-negra no estado do Rio Grande do Sul.

\section{DISCUSSION}

A characteristic that is sought for the modelling of volume and taper equations is to achieve compatibility, which means, that the volume estimates values do not differ from the values obtained using the integration of the taper function.

Compatibility was not achieved for the equations obtained using Procedure 1 . This evidence is undesirable because two different volumes are estimated for the same tree, which is not expected. The lack of additivity causes inconsistency in the volume estimate, and the discrepancy observed at the tree level gets even worse when volume estimators are taken for the forest stand area as a whole, or even for larger areas (large-scale inventories). 
In Procedure 2, the additivity of the fitted models is obtained because the total volume equation consists of the same coefficients of the taper equation. Additive equations are necessary to estimate total volume (which corresponds to the total volume of components) or stem components volume, which for the black wattle can be stomp and tops volume and volume for the woodchips industry.

The compatibility between the volume function and the taper function does not depend on the coefficient estimate process, because these depend on the restriction functions $(\beta)$. The estimator used to fit the equations will only reflect on the equations' efficiency. For instance, the models in Procedure 2 can be fitted using ordinary least squares, as done for Procedure 1. The importance of using a simultaneous estimator lies in the correlation between the random errors of the equations, which in this paper was 0.59, which is discussed by Diéguez-Aranda et al. (2006).

The modelling of volume equations compatible with the taper equation has been increasingly used. Recent applications were developed by Zhao et al. (2018), Corral-Rivas et al. (2017), Lynch et al. (2017), Zheng et al. (2017), Özçelik and Crecente-Campo (2016), Tang et al. (2016), Özçelik and Göçeri (2015), Özçelik and Brooks (2012), Nunes, Tomé and Tomé (2010), and Crecente-Campo et al. (2009).

In Brazil, there are today applications on the approach of volume and taper equations compatibility. The most significant are the research developed by Môra et al. (2014) and other that have been published in master dissertations before that. The only difference between the modelling approach of this paper and applications previously developed in Brazil is the fitting method, which considers the dependence of the equations using the residuals correlation.

\section{CONCLUSIONS}

The quality of the fitting for the volume and taper equations fitted using procedures 1 and 2 is similar.

- Both procedures tested are appropriate to estimate volumes and diameter along the stem. However, using Procedure 2 is recommended because it achieves compatibility when estimating volume using volume and taper functions.

- The volume incompatibility, in absolute terms, increases exponentially with the size of the tree.

- The system of equations presented in procedure 2 should be fitted using simultaneous fitting, preferably, because the residuals from the volume and taper equations are correlated.

\section{ACKNOWLEDGEMENTS}

The author acknowledges TANAGRO S.A. and TANAC S.A. for their support to conduct the field research, as well as the support by the Coordination for the Improvement of Higher Education Personnel (CAPES).

\section{REFERENCES}

CLUTTER, J.L. Development of taper functions from variable-top merchantable volume equations. Forest Science, v. 26, p. 117-120, 1980.

CRECENTE-CAMPO, F.; ALBORECA, A.R.; DIÉGUEZ-ARANDA, U. A merchantable volume system for Pinus sylvestris L. in the major mountain ranges of Spain. Annals of Forest Science, v. 66, p. 1- 12; 2009.

CORRAL-RIVAS, J.J.; VEGA-NIEVA, D.J.; RODRÍGUEZ-SOALLEIRO, R. et al. Compatible system for predicting total and merchantable stem volume over and under bark, branch volume and whole-tree volume of pine species. Forests, v. 8, p. 1-18, 2017.

DEMAERSCHALK, J.P. Taper equations can be converted to volume equations and point sampling factors. The Forestry Chronicle, v. 47, p. 352-354, 1971.

DEMAERSCHALK, J. Converting volume equations to compatible taper equations. Forest Science, v.18, n.3, p. 241-245, 1972.

DEMAERSCHALK, J. Integrated systems for the estimation of tree taper and volume. Canadian Journal of Forest Research, v.3, n.1, p. 90-94, 1973.

DIÉGUEZ-ARANDA, U.; CASTEDO-DORADO, F.; ÁlVAREZ-GONZÁles, J.G.; ROJO, A. Compatible taper function for Scots pine plantations in northwestern Spain. Canadian Journal of Forest Research, V. 36, p. 1190-1205, 2006.

KRISNAWATI, H. A compatible estimation model of stem volume and taper for Acacia mangium willd.

FLORESTA, Curitiba, PR, v. 50, n. 3, p. 1518 - 1526, jul/set 2020

Behling, M. et.al.

ISSN eletrônico 1982-4688

DOI: $10.5380 /$ rf.v50 i3. 63881 
Plantations. Indonesian Journal of Forestry Research. Pulau Fordate, v. 3, n. 1, p 49 - 64, 2016.

GOULDING, C.J.; MURRAY, J.C. Polynomial taper equations that are compatible with tree volume equations. New Zealand Journal of Forestry Science, v. 5, p. 313-322, 1975.

GREENE, W.H. Econometric analysis. Upper Saddle River: Prentice-Hall, 2008. 1178p.

KRISNAWATI, H. A compatible estimation model of stem volume and taper for Acacia mangium Willd. Plantations. Indonesian Journal of Forestry Research, v. 3, p. 49-64, 2016.

LYNCH, T.B.; ZHAO, D.; HARGES, W.; MCTAGUE; J.P. Deriving compatible taper functions from volume ratio equations based on upper-stem height. Canadian Journal of Forest Research, v. 47, p. 1424-1431, 2017.

MÔRA, M.; FIGUEIREDO FILHO, A.; KOHLER, S.V.; MIRANDA, R.O.V. Modelos para estimavas volumétricas de fustes de Pinus taeda L. Enciclopédia Biosfera, v. 10, n. 19, p. 1320-1332, 2014.

MUNRO, D.D.; DEMAERSCHALK, J.P. Taper-based versus volume-based compatible estimating systems. The Forestry Chronicle, v. 50, p. 197-199, 1974.

NUNES, L.; TOMÉ, J.; TOMÉ, M. A system for compatible prediction of total and merchantable volumes allowing for different definitions of tree volume. Canadian Forest Servic, v. 40, p. 747 - 760, 2010.

ÖZÇELIK, R.; BROOKS, J.R. Compatible volume and taper models for economically important tree species of Turkey. Annals of Forest Science, v. 69, p. 105-118, 2012.

ÖZÇELIK, R.; CRECENTE-CAMPO, F. Stem taper equations for estimating merchantable volume of lebanon cedar trees in the Taurus Mountains, Southern Turkey. Forest Science, v. 62, n.1, p. 78-91, 2016.

ÖZÇELIKK, R.; GÖÇERİ, M. F. Compatible merchantable stem volume and taper equations for eucalyptus plantations in the Eastern Mediterranean Region of Turkey. Turkish Journal of Agriculture and Forestry, v. 39 , p. $851-863,2015$.

RODRÍGUEZ, F.; LIZARRALDE, I.; BRAVO, F. Additivity on nonlinear stem taper functions: a case for corsican pine in northern Spain. Forest Science, v. 59, p. $464-471,2013$.

TANG, X.; PÉREZ-CRUZADO, C.; FEHRMANN, L. ÁlVAREZ-GONZÁLES, J. G.; LU, Y.; KLEINN, C. Development of a compatible taper function and stand-level merchantable volume model for chinese fir plantations. Plos One, v. 11, n. 1, p. 1 - 15, 2016.

ZHAO, D.; KANE, M. New variable-top merchantable volume and weight equations derived directly from cumulative relative profiles for loblolly pine. Forest Science, v. 63, n. 3: 261-269, 2017.

ZHAO, D. LYNCH, T.B.; WESTFAlL, J.; COULSTON, J.; KANE, M.; ADAMS, D.E. Compatibility, Development, and estimation of taper and volume equation systems. Forest Science, p. 1-13, 2018. DOI: https://doi.org/10.1093/forsci/fxy036

ZHENG, C.; WANG, Y.; JIA, L.; WE, S.; SUN, C.; DUAN, J. Compatible taper-volume models of Quercus variabilis Blume forests in north China. iForest - Bio geosciences and Forestry, v. 10, p. 567 - 575, 2017. 